\title{
Triploid forage grass hybrids Festuca apennina $\times F$. pratensis display extraordinary heterosis for yield characteristics
}

\author{
Beat Boller • David Kopecký 1
}

Received: 3 June 2020/Accepted: 13 August 2020/Published online: 20 August 2020

(C) The Author(s) 2020

\begin{abstract}
Hybrid vigor (or heterosis) is the overperformance of a hybrid over its parents in a specific trait or a set of traits. As such, hybrid breeding serves as a tool to efficiently trigger gains in breeding programs. Moreover, hybrids of genetically distant landraces, varieties or even species may become evolutionary successful. In Swiss alpine swards, we observed frequent prevalence of triploid hybrids of Festuca pratensis $\times F$. apennina with outstanding competitiveness relative to their parental species in the sites of sympatric occurrence. Observations of these highly vigorous hybrids prompted the study on their heterosis across various environmental conditions. Phenotypic observations during 3 years at four locations at different altitudes (from 200 to $1850 \mathrm{~m}$ a.s.1.) have shown significant heterosis for dry biomass production at all sites during the first and second year, and at the mid- and high altitude sites also in the third
\end{abstract}

Electronic supplementary material The online version of this article (https://doi.org/10.1007/s10681-020-02680-0) contains supplementary material, which is available to authorized users.

B. Boller

Zurich, Switzerland

D. Kopecký $(\square)$

Institute of Experimental Botany, Czech Academy of

Sciences, Centre of the Region Hana for Biotechnological

and Agricultural Research, Slechtitelu 31,

77900 Olomouc, Czech Republic

e-mail: kopecky@ueb.cas.cz year. At mid-altitude (1000 $\mathrm{m}$ a.s.l.), heterosis increased steadily and reached a maximum of $+508 \%$ for annual yield $(+626 \%$ for a single cut) in the third year. This is by far the highest value of heterosis ever reported for annual dry matter yield of a forage grass. Further utilization of triploid hybrids in forage grass breeding is hampered by their sterility. Hence there is a need for vegetative propagation. However, artificial chromosome doubling of triploids to create fertile hexaploids, or seeking ways to propagate them vegetatively at an industrial scale might overcome this limitation.

Keywords Heterosis · Triploid hybrid · Forage · Festuca $\cdot$ Alpine sward

\section{Introduction}

Heterosis, or hybrid vigor, is a genetic phenomenon where F1 hybrids outperform their parents. Arguably, the practical utilization of heterosis in plant breeding created the greatest revolution in agriculture in the 20th century. Apart from dramatic yield improvements in a wide range of crops, hybrid breeding provides a better control of crop genetics, and is of considerable benefit to breeding and seed companies, if not always the growers (Fehr 1987; Lippman and Zamir 2007; Casler and van Santen 2010). 
The levels of heterotic effects are different in different crops. Generally, heterosis is higher in crosspollinating than in self-pollinating species. When inbred lines of cross-pollinating species such as rye or maize are used to make hybrids, heterosis can reach almost $300 \%$ over the mid-parent (MP) value but considerably less when the performance of the parental populations (from which the inbred lines were developed) is used as the benchmark. In selfpollinating species, no more than 20\% MP heterosis can be expected (Becker 1992). The best-known examples of employing heterosis in practice are maize and pearl millet. In maize, Carena (2005) found an average $+20 \%$ MP heterosis in various environments, with up to the average of $+48 \%$ in subtropical locations of Mexico, Columbia and Thailand (Reif et al. 2003). In pearl millet, grain productivity increased in India from $305 \mathrm{~kg} \mathrm{ha}^{-1}$ in years 1951-1955 to $998 \mathrm{~kg} \mathrm{ha}^{-1}$ in years 2008-2012 due to the implementation of hybrid breeding, crop management and agricultural input use (Yadav et al. 2000). In West African pearl millet, grain yield showed an average MP heterosis of $+16.7 \%$, ranging from -26 to $+73 \%$ for individual hybrids. Similarly, up to $+81 \%$ BP (better-parent) heterosis was found in hybrids of African landraces grown for 2 years at two locations in Niger (Ouendeba et al. 1993).

Much debate concerns the proper selection of parents for crossings in hybrid breeding. The results are inconsistent. Posselt (2010) demonstrated a significant positive correlation between forage yield of perennial ryegrass hybrids and the geographical distance between their parental populations. On the other hand, genetic relationship between parents used for F1 hybrid production was not significantly correlated with heterosis for total herbage yield in hybrids of Italian ryegrasses (Wang et al. 2016). Similarly, geographical distance between two parents presumably reflecting genetic relationship does not always correlate with heterosis. For example, in pearl millet, inter-country crosses had about similar grain yield as intra-country crosses (Pucher et al. 2016). There are probably some prerequisites for positive correlation including high trait heritability. For that, absence of such correlation might be expected for total herbage yield with its low heritability. Moreover, heterosis in the same hybrid or hybrid population seems to differ under various environmental conditions. Pucher et al. (2016) found that heterosis varied in pearl millet from
$+4 \%$ at Samako (Mali) to $+47.3 \%$ at Bambey (Senegal). Breese (1969) found a trend for heterosis to be higher in poorer environmental conditions compared to high yielding sites. In line with this, slightly higher heterosis was observed in Lolium perenne L. hybrids under low-N compared to high-N growing conditions (Gaue et al. 2003).

In forage grasses, development of cultivars with improved dry matter yield and quality, and at the same time acceptable seed yield potentials, have been the main breeding targets over the last decades. However, in such major crops as Italian and perennial ryegrasses Lolium multiflorum Lam. and L. perenne L. only marginal improvements of the dry matter yield have been observed (Redfearn et al. 2005; Wilkins and Lovatt 2011). Here, the deployment of intervarietal or interspecific hybrids with high hybrid vigor could be highly beneficial. The highest heterosis observed in forage grasses to date $(+70 \%)$ was found in the interspecific hybrid L. perenne $\times$ L. multiflorum (Lein 1998). On the other hand, only meager heterosis was observed in intergeneric Festuca $\times$ Lolium hybrids (Ghesquiere et al. 2016). The level of hybrid vigor appears to be related to the genetic distance separating the parents (East 1936). Such distance between different genera would reasonably be expected to be greater than among more closely related taxa. In forage grasses, there are also other attributes speaking in favor of distant hybrids, such as complementarity of their agronomic and end-use profiles. This complementarity is the main driving force behind quite successful breeding of intergeneric hybrids of forage grasses of the Festuca-Lolium complex, collectively referred to as Festulolium.

One way to maintain high level of heterosis without a risk of inbreeding depression in subsequent generations is a change in the reproductive behavior from sexual to vegetative propagation. Some sterile interspecific hybrids with high heterosis may switch to asexual reproduction, such as apomixis or rhizomes, and become highly competitive to their parental species. Vegetatively reproducing triploid hybrids of diploid Festuca pratensis Huds. and F. apennina De Not. are abundant at altitudes between 1100 and $1900 \mathrm{~m}$ above sea level (a.s.l.) in Swiss Alps (Kopecký et al. 2016). Triploid hybrids were the only cytotype found in several locations indicating their high competitiveness. Besides presumed heterosis, clonal propagation is probably the main reason for 
their abundance. We found that they can disperse to a distance of at least $14 \mathrm{~m}$ by their rhizomes (Kopecký et al. 2018). Visual observation of these vigorous plants indicates their potential in forage grass breeding.

High frequency of such hybrids at a narrow altitude range (between 1100 and $1900 \mathrm{~m}$ a.s.l.) in the Swiss Alps prompted this study, to estimate heterosis in triploid $F$. pratensis $\times F$. apennina hybrids under different climatic conditions. Special attention is paid to the effect of altitude and the effect of heterosis on the high abundance of this hybrid in Swiss swards and potential for future breeding. In the course of this study an astonishing level of heterosis was observed, far surpassing published data so far.

\section{Materials and methods}

\section{Plant material}

Pairwise crosses between genotypes of tetraploid Festuca apennina (Fape) and diploid $F$. pratensis $(F p)$ were carried out in 2016 by the detached stem approach as described in Boller et al. (2018). Seeds were collected from each of the parental plants separately. Progenies were checked for ploidy by flow cytometry and triploids were assumed to be hybrids; diploids and tetraploids were assumed to have originated from self-pollination and were discarded. Hybrid origin of a sub-set of triploids was later confirmed by genomic in situ hybridization (see below). Two crosses (A and B) were selected for the study, with the highest number of triploid progeny. The Fape parents are part of the collection described in Kopecký et al. (2016). For cross A with 5 triploid progenies, the Fape parent originated from Moléson (Ct. Vaud, Switzerland), for cross B with 13 triploid progenies, from Stoos (Ct. Schwyz, Switzerland). Formal identification of the samples was undertaken by the authors. The $F p$ parents were two different elite genotypes of the Agroscope breeding program, with strong focus on disease resistance.

Half-sib families obtained from seed from the 4 open pollinated parental plants represented the parents. The two Fape parents had flowered among 14 genotypes selected from a a collection of Fape ecotypes. The two $F p$ parents had flowered in the same polycross with 6 other elite genotypes of the Agroscope breeding program. Half-sib progenies of the parental lines were used instead of the parental plants per se to compare plants of similar age and grown from seeds for all three groups.

Flow cytometry

The ploidy levels were estimated according to Dolezel et al. (2007) in nuclear suspensions prepared from $50 \mathrm{mg}$ of leaf tissue, with $F$. pratensis cv. Kolumbus used as the reference standard having $2 \mathrm{C}=6.49 \mathrm{pg}$ (Kopecký et al. 2010). Samples were analyzed using a CyFlow Space flow cytometer (Sysmex Partec GmbH., Görlitz, Germany) equipped with a UV led diode array. At least 5000 events were acquired per sample and only measurements with the coefficient of variation for G0/G1 peaks $<2.0 \%$ were accepted.

Genomic in situ hybridization (GISH)

GISH was done a subset of 20 plants according to Kopecký et al. (2016). A probe from the total genomic DNA of $F$. pratensis was labeled using the Dig-Nick Translation Mix (Roche); blocking DNA made by shearing total genomic DNA of $F$. glaucescens. The probe/block mix was applied to metaphase chromosome spreads and the probe hybridization signals were detected by the anti-DIG-FITC conjugate.

Meteorological conditions and field experiments

Eighteen triploid hybrids and 20 genotypes each of diploid $\mathrm{Fp}$ and tetraploid Fape, randomly selected from the half-sib families corresponding to the parents of the hybrids were propagated clonally in the greenhouse. At the time of planting, ramets had two to four tillers. The four best plantlets per genotype were chosen. For several genotypes, not enough ramets survived, resulting in some missing individuals in the experiments.

Four sites at altitudes ranging from 200 to $1850 \mathrm{~m}$ a.s.l. were chosen (Table 1, ESM 1). The sites differed in temperature, precipitation and soil properties. In general, temperature during the growing period (April-October) decreased with altitude by about $0.5{ }^{\circ} \mathrm{C}$ per $100 \mathrm{~m}$. Precipitation was the lowest at lowest site (Olomouc), and the highest at the $1000 \mathrm{~m}$ 
Table 1 Characteristics of the four experimental sites used for the field study

\begin{tabular}{|c|c|c|c|c|c|}
\hline Locality & & Olomouc & Reckenholz & Fruehbuehl & Maran \\
\hline Town & & $\begin{array}{l}\text { Olomouc- } \\
\text { Holice }\end{array}$ & Zürich & Walchwil & Arosa \\
\hline Country (canton) & & Czech Republic & Switzerland $(\mathrm{ZH})$ & Switzerland (ZG) & Switzerland (GR) \\
\hline \multirow[t]{2}{*}{ Co-ordinates } & Latitude & $4934.416 \mathrm{~N}$ & $4725.734 \mathrm{~N}$ & $476.847 \mathrm{~N}$ & $4647.589 \mathrm{~N}$ \\
\hline & Longitude & $1717.097 \mathrm{E}$ & $831.479 \mathrm{E}$ & $832.452 \mathrm{E}$ & $941.252 \mathrm{E}$ \\
\hline Altitude m.a.s.1 & & 200 & 440 & 1000 & 1850 \\
\hline Precipitation & 2017 (A0) & 385 & 699 & 1413 & 1026 \\
\hline (April-October) & $2018(\mathrm{H} 1)$ & 147 & 480 & 896 & 761 \\
\hline \multirow[t]{2}{*}{$\mathrm{mm}$} & $2019(\mathrm{H} 2)$ & 329 & 752 & 1417 & 1014 \\
\hline & 1981-2010 & N/A & 701 & 1329 & 912 \\
\hline $\begin{array}{l}\text { Mean air } \\
\text { temperature }\end{array}$ & 2017 (A0) & 15.57 & 15.23 & 12.55 & 8.64 \\
\hline (April-October) & $2018(\mathrm{H} 1)$ & 17.8 & 16.71 & 13.79 & 9.99 \\
\hline \multirow[t]{2}{*}{${ }^{\circ} \mathrm{C}$} & $2019(\mathrm{H} 2)$ & 16.22 & 15.10 & 12.48 & 8.94 \\
\hline & 1981-2010 & N/A & 14.30 & 11.47 & 7.77 \\
\hline Soil charactersistics & Soil type & Gleyic fluvisol & $\begin{array}{l}\text { Gleyic cambisol } \\
\text { (clayic) }\end{array}$ & $\begin{array}{l}\text { Loamy dystric } \\
\text { cambisol }\end{array}$ & $\begin{array}{c}\text { Loamy eutric } \\
\text { cambisol }^{\mathrm{a}}\end{array}$ \\
\hline
\end{tabular}

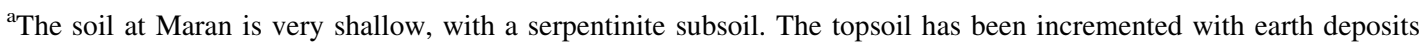

a.s.l. site, Fruehbuehl. The highest altitude site, Maran (1850 m a.s.l.), was clearly dryer than Fruehbuehl. Years 2017 (A0) and 2019 (H2) were about $1{ }^{\circ} \mathrm{C}$ warmer than the 1981-2010 mean and with average precipitation. Year 2018 was clearly warmer and much dryer than the average at all sites (ESM 1). With just $180 \mathrm{~mm}$ of precipitation from March to October, the summer 2018 at Olomouc had a prolonged period of drought. Soils at the two high altitude sites, Fruehbuehl and Maran, were less heavy and better drained than the ones at the low altitude sites, Reckenholz and Olomouc. Those two were gleyic, indicating there are periods of anaerobic conditions due to too much water and periods of physical stress caused by low water availability.

Field experiments were planted in a completely randomized block design. The experimental unit was a spaced plant with a distance of $50 \mathrm{~cm}$ between rows and $30 \mathrm{~cm}$ between plants within a row. At each site, four replications (blocks) were used with separate randomization of the 58 genotypes in each block. Trials were planted between April and June 2017 and maintained for three vegetation periods: the establishment year A0 (2017) and the first (H1, 2018) and second $(H 2,2019)$ full harvest years. All plants were cut 2-3 times in A0, 3-4 times in H1, and 2-3 times in $\mathrm{H} 2$. Early in spring and after each cut, except the last cut of a year, 50 units $(\mathrm{kg} / \mathrm{ha})$ of nitrogen were applied as ammonium nitrate.

The individual plant vigor was scored near the end of each growth cycle on a 1 (no growth) to 9 (maximum vigor) scale. Winter damage was rated at the beginning of the vegetation season in H1. Susceptibility to crown rust and bacterial wilt were rated on a 1 (no symptoms) to 9 (fully affected) scale when diseases occurred. The dry matter yield (DMY) was determined at one cut in $\mathrm{A} 0$, and at two cuts in $\mathrm{H} 1$ and H2. Herbage was clipped with a sickle, supported by a $3 \mathrm{~cm}$ high, V-shaped wooden template, after raising all tillers manually to the vertical. This resulted in stubble heights of about $5 \mathrm{~cm}$. At the three Swiss sites, the dry matter of all plants was weighed after ovendrying at $105{ }^{\circ} \mathrm{C}$ for $24 \mathrm{~h}$. At Olomouc, the fresh weight of each harvested plant was weighed at the field, and at least half the samples were oven-dried and weighed again. Then, dry matter of remaining plants was estimated from the fresh weight and the average dry matter content of the oven-dried plants. 
Statistical analyses

Data were analyzed using the GLM procedure of SAS version 9.4 (SAS Institute Inc., Cary, NC, USA). DMY and the average vigor were evaluated for each experimental site separately. For comparisons among sites, DMY was first converted to relative DMY by dividing the absolute DMY of each plant by the average DMY of all plants harvested at a particular site, multiplied by $100 \%$. Least squares means delivered by the GLM procedure were used to report the mean response of all hybrid and parental-species genotypes belonging to a cross (A or B). Significance of differences between these means was estimated by contrasts using the PDIFF option provided within the GLS procedure of SAS, considering genotypes within a particular progeny as a random effect. In order to evaluate differential growth response of genotypes to altitude, average yield over the two low (Olomouc and Reckenholz) and the two high (Fruehbuehl and Maran) altitude sites was calculated in a GLM analysis over all sites. Heterosis was calculated for each cross separately on the basis of least spares means over all genotypes per cross. Least squares means of the 5 halfsib progeny genotypes of the respective $F$. apennina and $F$. pratensis parents were used as a proxy to estimate performance of parents. Mid-parent (MP) heterosis $(\%)$ for yield (Y) was calculated as $\mathrm{Y}$ (triploid hybrid)/(Y(Fape parent)/2) $\times 100-100$. Better parent (BP) heterosis was calculated as $\mathrm{Y}$ (triploid hybrid $) / Y($ higher yielding parent $) \times 100-100$.

\section{Results}

All examined triploids (ca. 10\% of the total number of triploids used in the field study) had 14 chromosomes with the GISH signal of $F$. pratensis and 7 chromosomes without a signal (indicating $F$. glaucescens-like chromosomes originating from $F$. apennina), confirming their hybrid origin. It is assumed with confidence that all triploids used in this study were in fact $F$. apennina $\times F$. pratensis hybrids.

Heterosis and biomass production: forage dry matter yield and vigor

The relative dry matter yield (DMY) and visually assessed vigor of the triploid hybrids exceeded those of both their parents at both high altitude Swiss sites and in all three experimental years (Figs. 1, 2 and 3). The differences between the triploid hybrids and their parents were highly significant $(p<0.001)$ for both cross directions. The mid-parent heterosis ranged from +65 to $+508 \%$ in terms of DMY and from +2.04 to +4.42 in terms of the mean vigor scores. Both the mid-parent (MP) and the better-parent (BP) heterosis for DMY gradually increased throughout the experiment at both high-altitude sites, with the MP reaching a maximum of $+626 \%$ at Fruehbuehl for the last cut of H2 (2019), and + 392\% at Maran for the first cut of H2 (Fig. 4). The BP heterosis peaked simultaneously with the MP heterosis at +468 and $+370 \%$, respectively.

The two lowland sites, Olomouc (200 m a.s.1.) and Reckenholz (440 m a.s.l.), differed dramatically from the two high-altitude sites, but growth responses were similar at both sites. In A0, the hybrids had the highest yield of the three cytotypes. The difference between the hybrids and diploid $F p$ was significant in cross B, but not in cross A. In H1, yields of $F p$ and the hybrids were many times higher than those of tetraploid Fape at both sites, but the hybrids did not out-yield $F p$; DMY of triploids was significantly lower at Reckenholz. In H2, Fape stopped growing completely at both low-altitude sites, and the hybrids had significantly lower yields and vigor than Fp. MP heterosis fluctuated around $100 \%$ at Reckenholz for most of the time, except for a final increase to $+218 \%$ in H2 (Fig. 4). Conversely, the MP heterosis declined sharply in Olomouc after reaching a maximum of $+141 \%$ in the summer of H1 (2018), becoming negative throughout $\mathrm{H} 2$. In $\mathrm{A} 0$ and $\mathrm{H} 1$, the BP heterosis decreased from low values to zero at both low-altitude sites and became negative in Olomouc from the end of $\mathrm{H} 1$ and throughout $\mathrm{H} 2$. However, it recovered to about $+50 \%$ in Reckenholz in the second half of $\mathrm{H} 2$.

The two independent measures of biomass production used, the relative dry matter yield (DMY) and visual scores (vigor), showed very similar responses, even though DMY was measured only for one (A0) or two cuts $(\mathrm{H} 1, \mathrm{H} 2)$ while vigor was scored at each growth cycle (up to 5, based on the number of cuts). A comparison of vigor scores and DMY for individual cuts allowed determination of their mutual relationship. DMY increased logarithmically with the vigor scores in each case (Tab. ESM1). Overall, one-unit vigor score on the 1-9 scale corresponded to an 

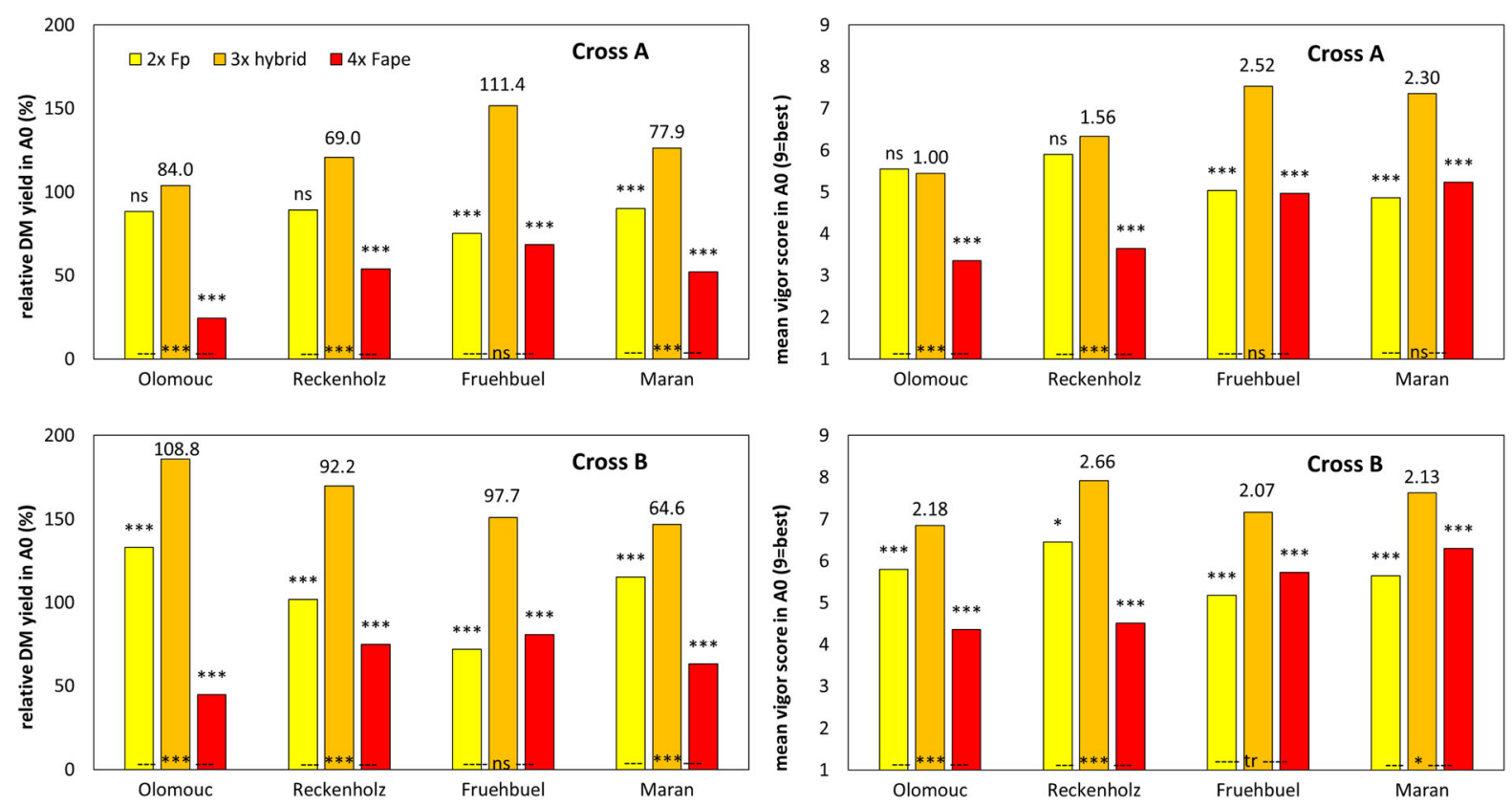

Fig. 1 Relative dry matter (DM) yield and mean vigor score of $2 \times F p, 4 \times$ Fape and their triploid $(3 \times)$ hybrids in the planting year (A0, 2017) at four experimental sites (Olomouc, Czech Republic; Reckenholz, Switzerland; Fruehbuehl, Switzerland and Maran, Switzerland). Figures above $3 \times$ hybrid columns indicate mid-parent (MP) heterosis of hybrids over

increase of $0.436 \mathrm{log}$ units, i.e. with a 1.54-fold increase of DMY. We used the vigor-DMY relationship calculated for each experimental site to estimate DMY at those instances where only vigor scores were taken. These estimated DMY scores were used along with the measured DMY to follow the development of heterosis over time at different locations.

\section{Survival over time}

Survival, the inverse of the death rate due to lack of adaptation, was an important component of large differences in the growth response of diploid $F p$, tetraploid Fape and their triploid hybrids between low- and high-altitude sites (Fig. 5). At low altitude sites, Fape was clearly not adapted to local conditions and no plant survived to the end of the experiment. At both sites, the summer of 2018 (H1) was the period of the most rapid loss of Fape plants. Diploid Fp survived best at low altitudes, and the hybrids behaved intermediately, but not much worse than Fp. At Fruehbuehl (1000 $\mathrm{m}$ a.s.l.) the hybrids were the best adapted with $100 \%$ survival to the end of the experiment. On

parental species (as \% for DM yield and as difference for vigor scores). Statistical annotations above $F p$ and Fape columns refer to difference to triploid hybrids, and those at the base of columns to difference between $F p$ and Fape as follows: ***p $<0.001$, $* * p<0.01 ; * p<0.05 ;$ tr $p<0.10$, ns not significant

contrary, several plants of both $F p$ and Fape died (mostly during $\mathrm{H} 2$ ), resulting in about $80 \%$ survival at the end of the experiment. At Maran (1850 m a.s.l.), all triploid hybrids and Fape plants survived and only few $F p$ plants died.

Genetic variation within species

In order to visualize variation among genotypes within each of Fp, Fape and their hybrids, average DMYs of each genotype at the two low-altitude sites were contrasted against the averages for the two highaltitude sites (Fig. 6). Fape genotypes performed relatively better at higher altitudes, while $F p$ genotypes performed better at low altitudes. Within both Fape and $F$, there was a positive correlation between the performance of individual genotypes at low and high altitudes, significant for Fape in A0 and H1 and for $F p$ in all 3 years. The hybrids behaved differently. With an increasing tendency from $\mathrm{A} 0$ to $\mathrm{H} 2$, there was a high variability among genotypes, from those performing much better at low altitude to those performing much better at high altitude. They showed 

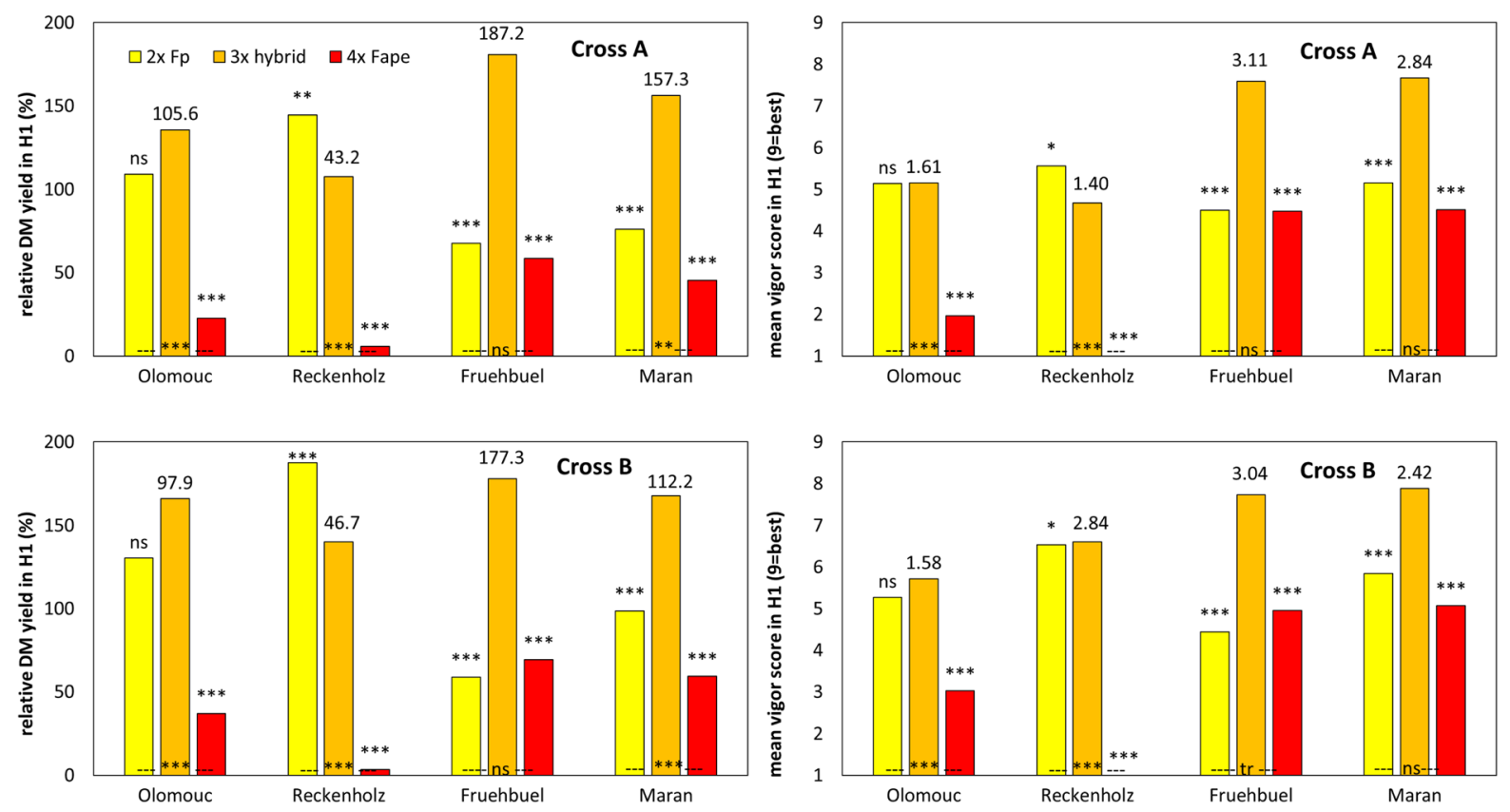

Fig. 2 Relative dry matter (DM) yield and mean vigor score of $2 \times F p, 4 \times$ Fape and their triploid $(3 \times)$ hybrids in the first full harvest year $(\mathrm{H} 1,2018)$ at four experimental sites (Olomouc, Czech Republic; Reckenholz, Switzerland; Fruehbuehl, Switzerland and Maran, Switzerland). Figures above $3 \times$ hybrid columns indicate mid-parent (MP) heterosis of

no or even a slightly negative correlation between performance at low and high altitudes. However, with one exception, the hybrids out-yielded all $F p$ and Fape plants in $\mathrm{H} 2$ at high altitudes and three of them also out-yielded all $F p$ and Fape plants at low altitudes. However, the hybrid which performed best at low altitudes was the second poorest at high altitudes in H2. Interestingly, this genotype (no. 117) was among those two derived from a seed harvested on the $F p$ parent. The other one of the two also performed much better at low than at high altitudes. Microscopic inspection revealed that both these hybrids were infected with the endophyte Neotyphodium uncinatum, as was their $F p$ mother.

Impact of disease susceptibility

Crown rust, a common disease caused by Puccinia coronata, occurred at Reckenholz and Fruehbuehl. Fape plants were highly susceptible, while $F p$ were nearly completely resistant (Fig. 7). The response of hybrids was not the same in the two crosses. In cross A, the hybrids were almost as susceptible as Fape (at

hybrids over parental species (as \% for DM yield and as difference for vigor scores). Statistical annotations above $F p$ and Fape columns refer to difference to triploid hybrids, and those at the base of columns to difference between $F p$ and Fape as follows: ***p $p 0.001$, ** $p<0.01$; $* p<0.05$; tr $p<0.10$, ns not significant

the first scoring at Reckenholz even more) indicating a positive heterosis for susceptibility. In cross B, the response was intermediate in the hybrids, and only as the second scoring at Reckenholz they were significantly more susceptible than their resistant $F p$ parent.

Bacterial wilt, a devastating disease of Lolium and Festuca species in lowland Switzerland caused by Xanthomonas translucens pv. graminis, markedly affected plants at Reckenholz. Similar to crown rust, $F p$ was highly resistant, while Fape was highly susceptible. The hybrids behaved intermediately, but exhibited positive heterosis for resistance, especially in the cross B. The hybrids and Fape showed a strong negative correlation between susceptibility to Xanthomonas and subsequent DMY throughout the remaining period of the experiment (ESM 2).

Winter damage was scored at each location as the proportion of brown (dead) leaves just before the start of spring growth. At both low altitude sites, Fape showed much higher winter damage than $F p$, with the hybrids behaving intermediately. Winter damage of the hybrids at Olomouc was more severe (close to Fape) when compared to Reckenholz, where it was 

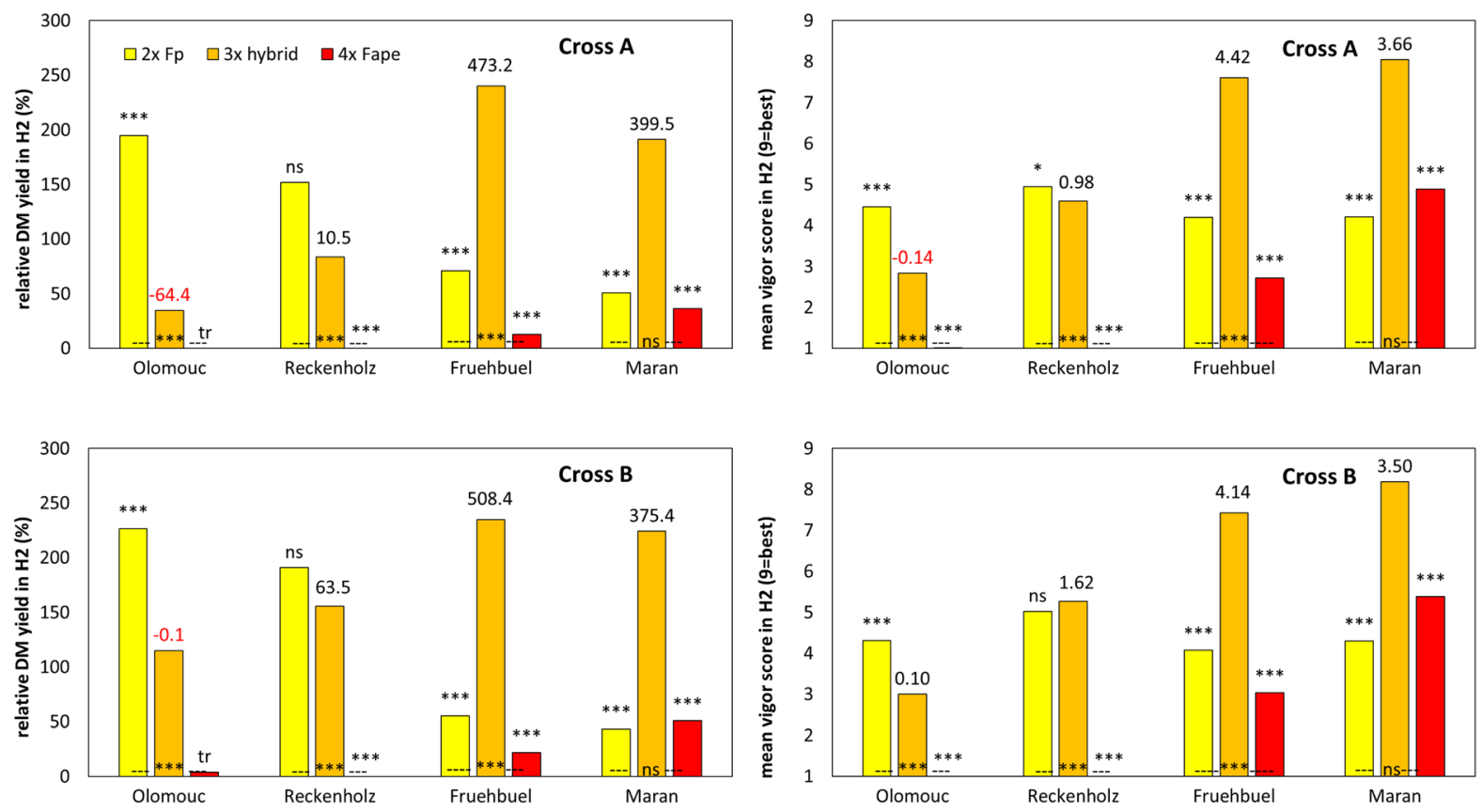

Fig. 3 Relative dry matter (DM) yield and mean vigor score of $2 \times F p, 4 \times$ Fape and their triploid $(3 \times)$ hybrids in the second full harvest year $(\mathrm{H} 2,2019)$ at four experimental sites (Olomouc, Czech Republic; Reckenholz, Switzerland; Fruehbuehl, Switzerland and Maran, Switzerland). Figures above $3 \times$ hybrid columns indicate mid-parent $(\mathrm{MP})$ heterosis of

hybrids over parental species (as \% for DM yield and as difference for vigor scores). Statistical annotations above $F p$ and Fape columns refer to difference to triploid hybrids, and those at the base of columns to difference between $F p$ and Fape as follows: ${ }^{* * *} p<0.001$, ${ }^{*} p<0.01$; ${ }^{*} p<0.05$; tr $p<0.10$, ns not significant
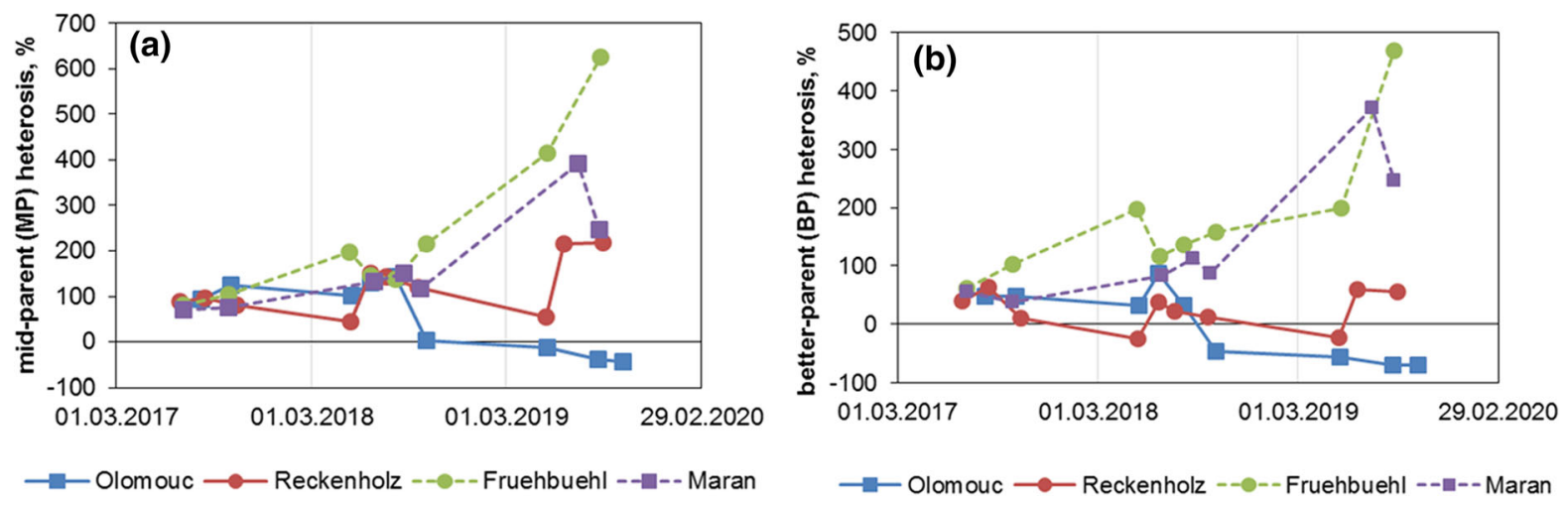

Fig. 4 Development of mid-parent (a) and better-parent (b) heterosis of $3 \times$ hybrids over their parents $2 \times F p$ and $4 \times$ Fape during experimental years A0 (2017), H1 (2018) and

H2 (2019) at four sites (Olomouc, Czech Republic; Reckenholz, Switzerland; Fruehbuehl, Switzerland and Maran, Switzerland)

almost as low as for $F p$. At both high-altitude sites, the hybrids were least damaged after winter, significantly less than Fp. For the highest altitude site Maran, Fape showed significantly less winter damage than $F p$, but the inverse was true for Fruehbuehl. In terms of winter damage, the two crosses A and B behaved identically.

\section{Discussion}

The level of heterosis can be measured in several different ways. Falconer and MacKay (1996) introduced the mid-parent (MP) heterosis as a difference between the trait performance of a hybrid and the 
Olomouc

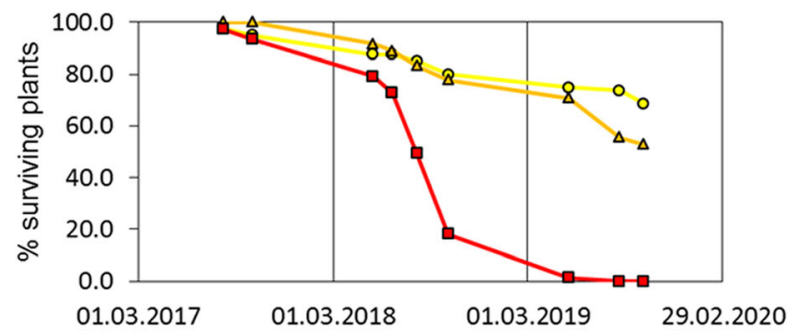

Früehbüehl

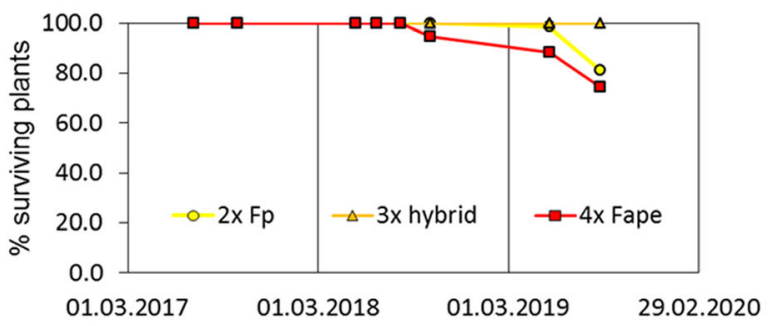

Reckenholz

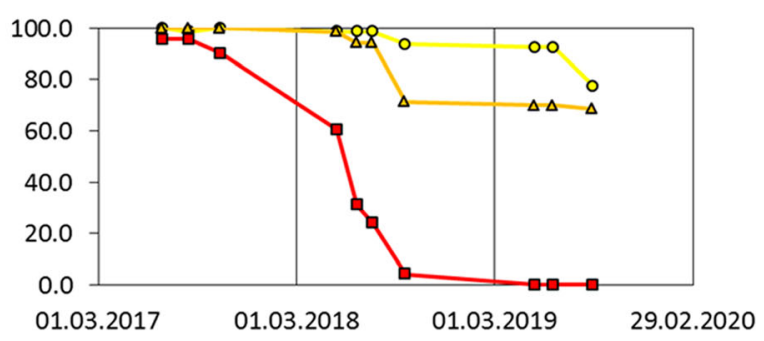

Fig. 5 Mortality of $2 \times F p, 4 \times$ Fape and their triploid $(3 \times)$ hybrids during experimental years A0 (2017), H1 (2018) and H2 (2019) at four sites (Olomouc, Czech Republic; Reckenholz, Switzerland; Fruehbuehl, Switzerland and Maran, Switzerland)
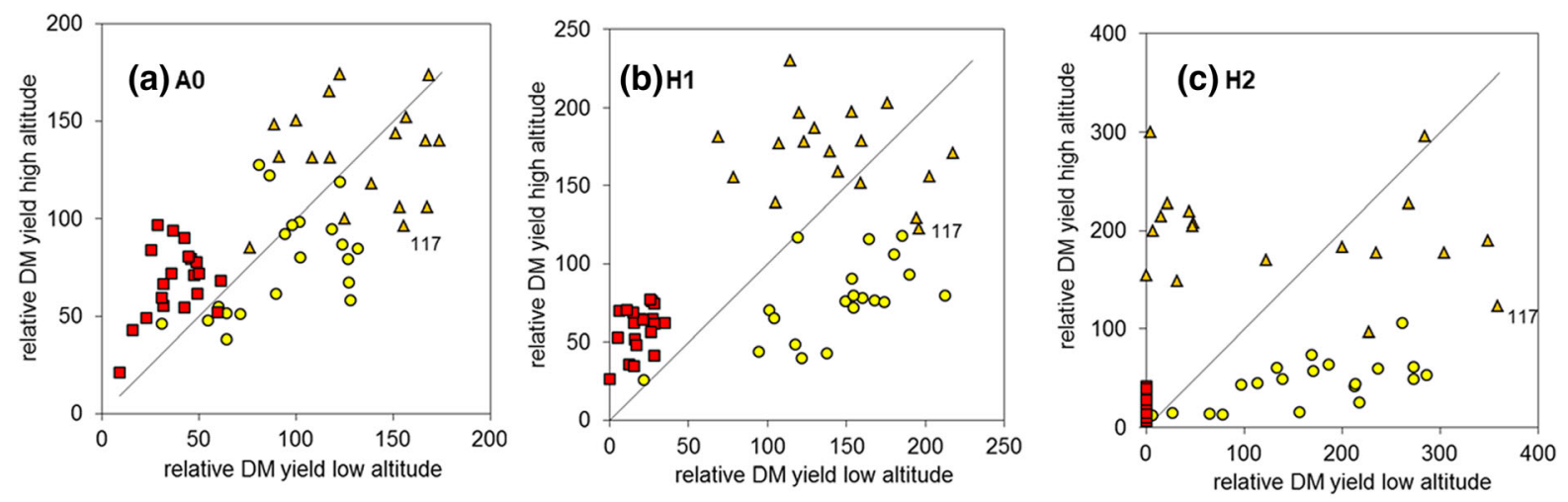

- $2 x \mathrm{Fp} \Delta 3 \mathrm{x}$ hybrid $\approx$ 4x Fape - high-low equal

Fig. 6 Genetic variation for annual dry matter yield among genotypes of $2 \times F p, 4 \times F a p e$ and their triploid $(3 \times)$ hybrids at low (sites Olomouc and Reckenholz) vs. high (sites Fruehbuehl and Maran) altitude in experimental years A0 (a), H1 (b), and H2 (c)

mean of the two parental lines. Occasionally, the better-parent (BP) heterosis is used. However, in outbreeding species, populations are often used for the hybrid production. For that, the panmictic mid-parent (PMP) and the panmictic better-parent (PBP) parameters of heterosis were established to reflect the performance of a hybrid population relative to its two parental populations (Lamkey and Edwards 1999). In this study, we use the MP and BP criteria.

Heterosis in forage grasses is usually studied under space planting and the heterotic effect appears to be more pronounced under this system than under sward conditions (Foster 1971, 1973; Posselt 1989). However, even when using spaced plants, PMP heterosis for yield is rather modest, from +1 to $+48 \%$ in Lolium perenne compared to -9 to $+8 \%$ when plots were used (reviewed in Posselt 2003). Here we decided on the spaced-plant experimental design, for several reasons, including convenience and the ability to gather a wider range of observations than that possible in a sward. 

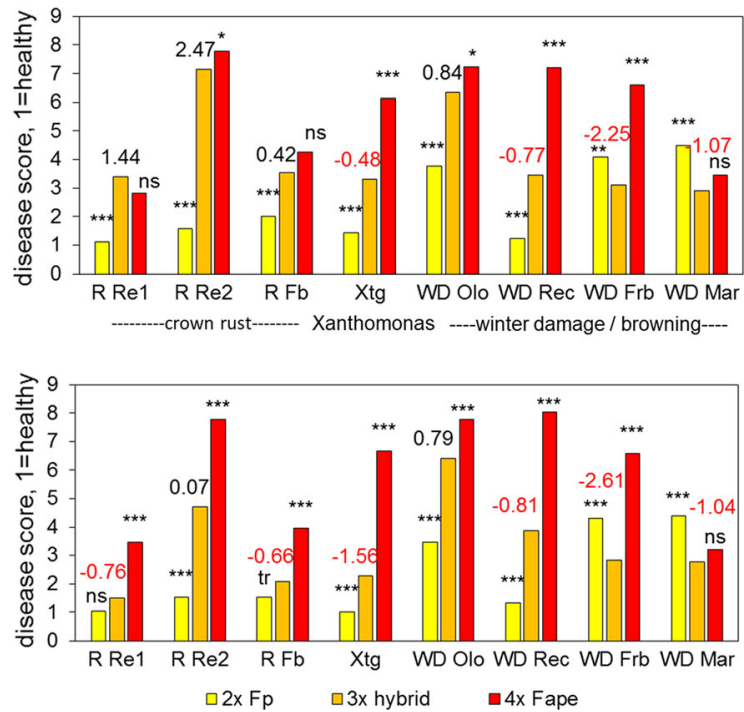

Fig. 7 Susceptibility to crown rust (R), bacterial wilt (Xtg) and winter damage (WD) of $2 \times F p, 4 \times$ Fape and their triploid $(3 \times)$ hybrids in cross A (top) and cross B (bottom). Visual disease scores $(1=$ healthy, $9=$ fully affected $)$ taken at Reckenholz (rust Re1 and Re2, Xtg) and Fruehbuehl (rust Fb), and scores of winter damage at Olomouc (WD Olo), Reckenholz (WD Rec), Fruehlbuehl (WD Frb) and Maran (WD Mar). Figures above $3 \times$ hybrid columns represent mid-parent heterosis as difference in scores, with negative values pointing to positive heterosis for resistance. Statistical annotations (see Fig. 1) refer to significance of difference between $3 \times$ hybrids and their parents. All scores were highly significantly $(p<0.001)$ different between $2 \times F p$ and $4 \times$ Fape

Extent of heterosis for dry matter yield

Very large mid-parent (MP) and better-parent (BP) heterosis values for the hybrids of non-inbred $F p$ and Fape observed here were far greater than any values reported so far in forage grasses. Posselt (2003) cited 15 studies involving 5 different forage grass species in a range of environments with a maximum MP heterosis for the annual forage yield of $+70 \%(19 \%$ on average), compared to over $+500 \%$ in our study. For individual cuts, the maximum MP heterosis reported by Posselt (2003) was $+152 \%$, compared to $+625 \%$ here with a comparable experimental design (individual spaced plants). Other studies with sown plots yielded even lower heterosis, usually less than $+20 \%$ (Posselt 1993; Wang et al. 2016).

Interestingly, the highest reported heterosis values so far were observed in an interspecific hybrid, $L$. perenne $\times$ L. multiflorum $($ Posselt 2003). Interspecific hybrids within the Festuca-Lolium complex, commonly referred to as Festulolium, are of interest mainly to combine stress resilience of Festuca species with productivity and quality of Lolium species. Heterosis for yield per se is rather small (Ghesquiere et al. 2016). Humphreys et al. (2014) report yields similar to, at best $10 \%$ higher than the respective Lolium parent for the most successful Festulolium candidates. Our triploid Fape $\times F p$ hybrids provide an example of an interspecific hybrid within the Festuca-Lolium complex with a high potential for heterosis for forage yield. This may add a new dimension to the discussion of the potential of interspecific forage grass hybrids. Indeed, exploitation of heterosis is considered a highly promising approach to speed up the supposedly low progress in breeding of forage grasses for yield (Herridge et al. 2019). Several approaches are followed, such as developing doubled haploids (Begheyn et al. 2016), cytoplasmic male sterility (cms) in hybrid production (Islam et al. 2014; Sykes et al. 2017), using the S-Z-self-incompatibility system to develop inbred lines (Do Canto et al. 2016) as well as optimizing the construction of self-incompatible hybrids (Pembleton et al. 2015). However, the use of interspecific hybrids to exploit heterosis for forage yield is not among the prime approaches followed, even though some promising examples exist, such as the energy grass Miscanthus 'Giganteus', an interspecific hybrid between Miscanthus sinensis and Miscanthus ogiformis (Robson et al. 2013).

It is somewhat surprising that our interspecific hybrid between two closely related species of Festuca show such a large heterosis for biomass yield. $F$. apennina (Fape) is morphologically so similar to $F$. pratensis $(F p)$ that in older literature it was referred to as a subspecies (Hegi 1908; Conert 1998) or even a varietas of $F$. pratensis (Stebler 1904). However, recent studies clearly show that $F$. apennina is an allotetraploid originating by hybridization of a progenitor of the current $F$. pratensis with a so-far unidentified species related to the modern $F$. glaucescens (Kopecký et al. 2016). One would, nevertheless, expect little heterosis because the $F p$ genome is present in Fape. However, $F p$ showed about five times more genetic diversity (estimated by DArT markers) than Fape, suggesting that the $F p$ genome present in Fape is only distantly related to modern $F p$ (Kopecký et al. 2018). Generally, heterosis increases as the 
genetic disparity of the parents or parental populations increases and interspecific hybrids seem to display greater heterosis than intraspecific hybrids (East 1936).

The triploid Fape $\times F p$ hybrids are almost completely sterile. This can be considered an advantage in nature because it guarantees long term stability of $F_{1}$ hybridity. Advanced generations of Festulolium hybrids show much less heterosis than would be expected from their $\mathrm{F}_{1}$ hybrids (Marc Ghesquiere, personal communication). Since our Fape $\times F p$ hybrids can efficiently propagate vegetatively through rhizomes (Kopecký et al. 2018), heterosis is conserved and can be expected to contribute significantly to their competitiveness in natural grassland. Highly competitive populations of the triploid hybrids were observed at mid-altitude sites (Kopecký et al. 2018). They dominated the swards in several locations and were the unique cytotype of all 54 Festuca specimens collected in one location at $1350 \mathrm{~m}$ a.s.l. However, sterility of triploid hybrids is an obvious obstacle for their further exploitation in grass breeding and agriculture.

Effect of altitude on relative performance of triploid hybrids and their parents

The performance of triploid hybrids relative to their parents was affected by the altitude of the trial site, and this effect increased over time. In the year A0, the MP heterosis ranged among the sites from +64 to $+111 \%$ without a clear altitudinal pattern (Fig. 1). In $\mathrm{H} 1$, it was lower, at about $+45 \%$ at Reckenholz (440 $\mathrm{m}$ a.s.1.) but increased to about $+180 \%$ at Fruehbuehl (1000 $\mathrm{m}$ a.s.1.) and about $+140 \%$ at Maran (1850 m a.s.l.) (Figure 2). At Olomouc (200 m a.s.1.), the relative performance of hybrids was better than at Reckenholz, but not as good as at Maran. In H2, a clear altitudinal pattern was observed (Fig. 3), with negative values for the MP heterosis at Olomouc, low values at Reckenholz, and an overarching maximum at Fruehbuehl of about $+500 \%$. In H2, the MP heterosis was also high in Maran, with over $+350 \%$. These patterns were highly consistent for both crosses (A and B) investigated. The highest levels of precipitation combined with a deep, well-drained soil at the midaltitude site, Fruehbuehl (ESM 1), probably contributed to good performance of Fape relative to $F p$, and to the maximum expression of heterosis in the hybrids. The shallow soil at Maran with poorer water holding capacity and nutrient delivery potential was probably responsible for the poorer relative performance of Fape, compared to Fruehbuehl, and the somewhat lesser expression of heterosis. The altitudinal and temporal patterns of the MP heterosis were related to the relative performance of the two parental species, Fape and Fp. When Fape performed very poorly compared to $F p$, such as at low altitude in $\mathrm{H} 2$, the MP heterosis of triploid hybrids was also low or even negative. When Fape performed moderately well, higher values for the MP heterosis were observed. In $\mathrm{H} 2$, a consistent altitudinal pattern of the relative performance of $F p$ and Fape was reached, with performance of Fape rising steadily with altitude.

Impact of biotic and abiotic stresses

Gradual dying of Fape plants to extinction during the last year of the experiment at low altitudes was responsible for their overall low performance at Olomouc and Reckenholz. At Reckenholz, bacterial wilt was the most damaging factor. Some plants died already during the spring 2018 when the disease was scored, and a dramatic loss of plants occurred after the first cut in H1. Yield losses and lack of regrowth after cutting is a common feature of heavy infestation with Xanthomonas (Egli et al. 1975; Egli and Schmidt 1982). Therefore, relatively good Xanthomonas resistance of the hybrids contributed to the longer persistence of positive heterosis for yield at the Reckenholz site. At Olomouc, summer drought in 2018 was the likely cause of Fape death. While most $F$ ape plants survived until the second cut, a significant loss of plants occurred in July and August when the drought and heat were the most severe. The hybrids responded differently to these stresses. At Reckenholz, the hybrids showed considerable variation in the susceptibility to Xanthomonas. Resistant plants survived without visible symptoms and kept producing biomass, while the susceptible ones reduced growth, and $25 \%$ died during 2018. This produced a very strong negative correlation between the Xanthomonas susceptibility and yields of hybrids (ESM 2). This correlation was also highly significant for Fape, but low and insignificant for the largely resistant $F p$. Over all genotypes in the study, Xanthomonas susceptibility was also highly significantly and negatively correlated with subsequent yield, reflecting the higher susceptibility of Fape and, to a lesser extent, the hybrids, 
compared to resistant Fp. Resistance to Xanthomas appears to be controlled by few major genes (Studer et al. 2006). The two elite $F p$ plants which were used to produce our triploid hybrids were from the Agroscope breeding program after several cycles of recurrent selection for Xanthomonas resistance, and likely carried such genes. The marked segregation among the triploids from crosses with a highly susceptible Fape plant suggests heterozygosity for resistance genes in the $F p$ parents. The response of triploid to the dry conditions at Olomouc was more gradual. Similar numbers of $F p$ plants and the hybrids survived the drought in $\mathrm{H} 1$ (Fig. 5), but yields of the hybrids relative to $F p$ (the better parent) declined significantly during H1 (2018) (see Fig. 4). Attrition of the hybrids continued in $\mathrm{H} 2$ and yield decreased further. Among the Fape $\times F p$ hybrids, a higher drought tolerance of the $F p$ parent was apparently not sufficient to adequately reduce the high water requirement of the Fape parent. Probably, the difficult soil conditions at Olomouc contributed to the poor performance of Fape and the hybrids after the drought of summer 2018.

At low altitude, Fape plants were seriously damaged after winter (brown leaves). As such, this dormancy response can express a survival mechanism. On the other hand, it results in slow spring growth and lower first cut yields, compared to the winter green $F p$ with hardly any signs of winter damage. The hybrids were intermediate between Fape and Fp. However, at the highest altitude (Maran), Fape and the hybrids showed significantly less winter damage by snow mold caused by Microdochium nivale) than Fp. A peculiar situation was observed at Fruehbuehl. Here, the hybrids showed negative heterosis for winter damage. Apparently, hybrids were less winter dormant than Fape and less susceptible to snow mold than $F p$ and thus they showed strong heterosis.

The hybrids derived from the two crosses A and B differed markedly in their response to crown rust infection. Hybrids from cross A showed a strong positive heterosis for susceptibility (negative for resistance), while those from cross $B$ were intermediate between susceptible Fape and resistant $F p$, not significantly more susceptible than $F p$ in two out of three scorings, and thus showed negative heterosis for susceptibility (positive for resistance). Indeed, rust susceptibility/resistance was the only case of negative heterosis for one, and positive for the other cross. This differential response points to a different architecture of the rust resistance in the two parent $F p$ plants. The crown rust resistance in the Festuca-Lolium complex is polygenic, as evidenced by a successful genomic prediction model to select for rust resistance in perennial ryegrass (Arojju et al. 2018). Two major and a number of minor QTLs for rust resistance in a segregating pseudo-testcross population of Italian ryegrass were identified (Studer et al. 2007). Schubiger and Boller (2017) demonstrated the prevalence of several independent race-specific major genes, each of which showed dominant, Mendelian segregation in cross progenies of perennial ryegrass. Likely, the $F p$ parent of cross B possesses some dominant, partly homozygous major resistance genes, while the resistance of the $F p$ parent of cross A relies mostly on minor resistance genes overridden by susceptibility genes of the Fape parent.

\section{Conclusions}

The triploid Fape $\times F p$ hybrid investigated in this study provided by far the highest values for the midparent heterosis ever reported for forage crops. This points to a hitherto unexploited potential of heterosis for biomass yield within the economically important Festuca-Lolium complex. Maximum levels of heterosis were only observed in a specific environment, at mid-altitude in Switzerland. This environment is squarely half way between the natural ranges of the two parental species: low-altitude (up to about $900 \mathrm{~m}$ a.s.1.) for $F p$ and high-altitude (above $1500 \mathrm{~m}$ a.s.l.) for Fape. Thus, at mid-altitude, factors responsible for the altitudinal limitation of occurrence of the parent species prevail at an intermediate expression and thus provide an ideal environment for the interspecific hybrid. High heterosis of the hybrids at mid-altitude reflects their dominance over the two parent species observed in natural grassland, suggesting that heterosis plays an important role in their evolutionary success in these habitats. At present, practical exploitation of such interspecific hybrids with large heterotic effects in agriculture is hampered by their sterility. Perhaps chromosome doubling in such hybrid will not only restore fertility but also fix the heterotic effects. Alternatively, an industrial-scale vegetative propagation should be explored. 
Acknowledgements This research was funded by the Czech Science Foundation (Grant award 20-10019S) and by the European Regional Development Fund OPVVV project "Plants as a tool for sustainable development" number CZ.02.1.01/0.0/ 0.0/16_019/0000827 supporting Excellent Research at CRH. We would like to thank Prof. Adam J. Lukaszewski (University of California, Riverside) for his critical reading and valuable comments and Dr. Jana Č́žžková and Eva Jahnová for assistance with flow cytometry analyses. We thank Agroscope for permitting us to use the experimental sites at Reckenholz, Fruehbuehl and Maran. This manuscript has been released as a pre-print at Research Square (Boller and Kopecký 2020).

Author's Contribution B.B. prepared plant material and designed the experiment, D.K. conducted flow cytometry and in situ hybridization analyses, B.B. and D.K. conducted the field phenotyping experiments and wrote the manuscript. Both authors approved the submitted version.

\section{Compliance with ethical standards}

Conflict of interest The authors declare that they have no conflict of interest.

Open Access This article is licensed under a Creative Commons Attribution 4.0 International License, which permits use, sharing, adaptation, distribution and reproduction in any medium or format, as long as you give appropriate credit to the original author(s) and the source, provide a link to the Creative Commons licence, and indicate if changes were made. The images or other third party material in this article are included in the article's Creative Commons licence, unless indicated otherwise in a credit line to the material. If material is not included in the article's Creative Commons licence and your intended use is not permitted by statutory regulation or exceeds the permitted use, you will need to obtain permission directly from the copyright holder. To view a copy of this licence, visit http://creativecommons.org/licenses/by/4.0/.

\section{References}

Arojju SK, Conaghan P, Barth S, Milbourne D (2018) Genomic prediction of crown rust resistance in Lolium perenne. BMC Genet 19:35

Becker HC (1992) Hybridforädleningens framtidsutsikter hos växter men olika naturliga reproduktionssätt. Sveriges Utsädesförenings Tidskrift 102:58-67

Begheyn RF, Lubberstedt T, Studer B (2016) Haploid and doubled haploid techniques in perennial ryegrass (Lolium perenne L.) to advance research and breeding. AgronomyBasel 6:60

Boller B, Kopecký D (2020) Extraordinary heterosis found in a forage grass hybrid, Festuca apennina $\times F$. pratensis. Research Square 13240 [Preprint]. February 5, 2020 [cited May 26, 2020]. https://doi.org/10.21203/rs.2.22666/v1

Boller B, Felder T, Kopecky D (2018) Tetraploid Festuca apennina is prone to produce triploid hybrid progeny when crossed with diploid Festuca pratensis. In: Brazauskas G, Statkevičiute G, Jonavičiene K (eds) Breeding grasses and protein crops in the era of genomics. Springer International Publishing, Cham, pp 33-38

Breese EL (1969) Measurement and significance of genotypeenvironment interactions in grasses. Heredity 24:27-44

Carena MJ (2005) Maize commercial hybrids compared to improved population hybrids for grain yield and agronomic performance. Euphytica 141:201-208

Casler MD, van Santen E (2010) Breeding objectives in forages. Fodder Crops Amenity Grasses 5:115-136

Conert JC (1998) Gustav Hegi: Illustrierte Flora von Mitteleuropa. Band 1, Teil 3. Spermatophyta: Angiospermae: Monocotyledones 1 (2). Poaceae (Echte Gräser oder Süssgräser). Parey Buchverlag, Berlin

Do Canto J, Studer B, Lubberstedt T (2016) Overcoming selfincompatibility in grasses: a pathway to hybrid breeding. Theor Appl Genet 129:1815-1829

Dolezel J, Greilhuber J, Suda J (2007) Estimation of nuclear DNA content in plants using flow cytometry. Nat Protoc 2:2233-2244

East EM (1936) Heterosis. Genetics 21:375-397

Egli T, Schmidt D (1982) Pathogenic variation among the causal agents of bacterial wilt of forage grasses. Phytopatholog $\mathrm{Z}$ 104:138-150

Egli T, Goto M, Schmidt D (1975) Bacterial wilt, a new forage grass disease. Phytopathol Z. 82:111-121

Falconer DS, MacKay TFC (1996) Introduction to quantitative genetics. Longman, Essex

Fehr WR (1987) Principles of cultivar development: theory and technique. Macmilla Publishing CO, New York

Foster CA (1971) Interpopulational and intervarietal hybridization in Lolium perenne breeding-heterosis under non-competitive conditions. J Agric Sci 76:107-130

Foster CA (1973) Interpopulational and intervarietal f1 hybrids in Lolium perenne-performance in field sward conditions. J Agric Sci 80:463-477

Gaue I, Luesink W, Walters L, Dolstra O, Frauen M (2003) Performance of F1-hybrids in Lolium perenne under different nitrogen regimes. In: Proceedings of the 24th EUCARPIA fodder crops and amenity grasses section meeting, vol 59. Braunschweig-FAL, pp 116-120

Ghesquiere M, Baert J, Barth S, Černoch V, Grogan D, Humphreys MW, Murray P, Ostrem L, Sokolović D, Paszkowski E, Zwierzykowski Z (2016) Enhancing the productivity in forage grasses on the European scale using interspecific hybridization. In: Roldán-Ruiz I, Baert J, Reheul D (eds) Breeding in a world of scarcity. In: Proceedings of the 2015 meeting of the section "Forage Crops and Amenity Grasses" of Eucarpia. Springer International Publishing, pp 199-204

Hegi G (1908) Illustrierte Flora von Mittel-Europa. Mit besonderer Berücksichtigung von Deutschland, Österreich und der Schweiz. J.F.Lehmann Verlag, München

Herridge R, Macknight R, Brownfield L (2019) Prospects for F1 hybrid production in ryegrass. New Zealand Journal of Agricultural Research 1-11

Humphreys MW, O’Donovan SA, Farrell MS, Gay AP, Kingston-Smith AH (2014) The potential of novel Festulolium $(2 n=4 \times=28)$ hybrids as productive, nutrient-use-efficient fodder for ruminants. Food Energy Sec 3:98-110 
Islam MS, Studer B, Moller IM, Asp T (2014) Genetics and biology of cytoplasmic male sterility and its applications in forage and turf grass breeding. Plant Breed 133:299-312

Kopecký D, Havrankova M, Loureiro J, Castro S, Lukaszewski AJ, Bartos J, Kopecka J, Dolezel J (2010) Physical distribution of homoeologous recombination in individual chromosomes of Festuca pratensis in Lolium multiflorum. Cytogenet Genome Res 129:162-172

Kopecký D, Harper J, Bertas J, Gasior D, Vrana J, Hribova E, Boller B, Ardenghi NMG, Simonikova D, Dolazel J, Humphreys MW (2016) An increasing need for productive and stress resilient festulolium amphiploids: what can be learnt from the stable genomic composition of Festuca pratensis subsp. apennina (De Not) Hegi? Front Environ Sci 4:66

Kopecký D, Felder T, Schubiger FX, Mahelka V, Bartos J, Dolezel J, Boller B (2018) Frequent occurrence of triploid hybrids Festuca pratensis $\mathrm{x} F$. apennina in the Swiss Alps. Alpine Bot 128:121-132

Lamkey KR, Edwards JW (1999) Quantitative genetics of heterosis. Genet Exploit Heterosis Crops, pp 31-48

Lein V (1998) Heterosis in crosses between inbred lines of $L$. perenne $\times$ L. multiflorum. $\mathrm{Ph}$.D. Thesis, Göttingen

Lippman ZB, Zamir D (2007) Heterosis: revisiting the magic. Trends Genet 23:60-66

Ouendeba B, Ejeta G, Nyquist WE, Hanna WW, Kumar A (1993) Heterosis and combining ability among african pearl-millet landraces. Crop Sci 33:735-739

Pembleton LW, Shinozuka H, Wang JP, Spangenberg GC, Forster JW, Cogan NOI (2015) Design of an F-1 hybrid breeding strategy for ryegrasses based on selection of selfincompatibility locus-specific alleles. Front Plant Sci 6:764

Posselt UK (1989) Comparison of progeny-testing methods in Lolium perenne $\mathrm{L} 1$ polycross vs topcross progenies using CMS-tester lines. Plant Breed 103:149-152

Posselt UK (1993) Hybrid production in Lolium perenne based on incompatibility. Euphytica 71:29-33

Posselt UK (2003) Heterosis in grasses. Czech J Genet Plant Breed 39:48-53

Posselt UK (2010) Identification of heterotic patterns in perennial ryegrass. In: Sustainable use of genetic diversity in forage and turf breeding, pp 569-572

Pucher A, Sy O, Sanogo MD, Angarawai II, Zangre R, Ouedraogo M, Boureima S, Hash CT, Haussmann BIG (2016) Combining ability patterns among West African pearl millet landraces and prospects for pearl millet hybrid breeding. Field Crops Res 95:9-20
Redfearn DD, Venuto BC, Pitman WD, Blouin DC, Alison MW (2005) Multilocation annual ryegrass cultivar performance over a twelve-year period. Crop Sci 45:2388-2393

Reif JC, Melchinger AE, Xia XC, Warburton ML, Hoisington DA, Vasal SK, Srinivasan G, Bohn M, Frisch M (2003) Genetic distance based on simple sequence repeats and heterosis in tropical maize populations. Crop Sci 43:1275-1282

Robson P, Jensen E, Hawkins S, White SR, Kenobi K, CliftonBrown J, Donnison I, Farrar K (2013) Accelerating the domestication of a bioenergy crop: identifying and modelling morphological targets for sustainable yield increase in Miscanthus. J Exp Bot 64:4143-4155

Schubiger FX, Boller B (2017) Genetic analysis of crown rust (Puccinia coronata f. sp. lolii) resistance in a perennial ryegrass (Lolium perenne) genotype. Euphytica 213:167

Stebler FG (1904) Jahresbericht der Schweizerischen Samenuntersuchungs-und Kontrollstation Zürich. Schweizerisches Landwirtschaftliches Jahrbuch 18:43

Studer B, Boller B, Herrmann D, Bauer E, Posselt UK, Widmer F, Koelliker R (2006) Genetic mapping reveals a single major QTL for bacterial wilt resistance in Italian ryegrass (Lolium multiflorum Lam.). Theor Appl Genet 113:661-671

Studer B, Boller B, Bauer E, Posselt UK, Widmer F, Kolliker R (2007) Consistent detection of QTLs for crown rust resistance in Italian ryegrass (Lolium multiflorum Lam.) across environments and phenotyping methods. Theor Appl Genet 115:9-17

Sykes T, Yates S, Nagy I, Asp T, Small I, Studer B (2017) In silico identification of candidate genes for fertility restoration in cytoplasmic male sterile perennial ryegrass (Lolium perenne L.). Genome Biol Evol 9:351-362

Wang JP, Pembleton LW, Cogan NOI, Forster JW (2016) Evidence for heterosis in Italian ryegrass (Lolium multiflorum Lam.) based on inbreeding depression in F-2 generation offspring from biparental crosses. Agronomy-Basel 6:49

Wilkins PW, Lovatt JA (2011) Gains in dry matter yield and herbage quality from breeding perennial ryegrass. Ir J Agric Food Res 50:23-30

Yadav OP, Weltzien-Rattunde E, Bidinger FR, Mahalakshmi V (2000) Heterosis in landrace-based topcross hybrids of pearl millet across arid environments. Euphytica 112:285-295

Publisher's Note Springer Nature remains neutral with regard to jurisdictional claims in published maps and institutional affiliations. 